\title{
PEMANFAATAN TAMAN KOTA 17 MEI TAPIN SEBAGAI SUMBER BELAJAR IPS
}

Ahmad Irawan Rafsanjani

1810128210030

\section{Program Studi Pendidikan IPS, FKIP Universitas Lambung Mangkurat}

\section{0@mhs.ulm.ac.id}

\begin{abstract}
Abstrak
Taman 17 Mei yang terletak di kabupaten Tapin Rantau yang mana taman ini merupakan satusatunya yang ada di Provinsi Kalimantan Selatan hingga saat ini. Yang mana selain sebagai tempat bermain pada taman kota Tapin disini terdapat juga sumber belajar yang cocok di implementasikan pada pembelajaran IPS yang mana apabila dimanfaatkan sebagai sumber belajar yang tepat tentunya akan menjadi sumber belajar yang menarik. Yang mana ada terdapat ukiran relief di dinding tembok yang ada ditaman ini ukiran relief ini menceritakan tentang aksi perjuangan masyarakat Banjar melawan para tentara kompeni Belanda di Taman 17 Mei tersebut. Yang mana menarik sekali untuk dimanfaatkan sebagai sumber belajar khususnya dari segi sejarah karena relief ini kental sekali dengan sisi dan juga nilai historisnya. Dan selain relief tadi ditaman ini terdapat juga teks proklamasi masyarakat Banua Anam, yang mana pada masa itu dibacakan langsung oleh pemimpin Divisi ALRI Pertahanan Kalimantan Selatan, yakni oleh Brigjen Hasan Basri. Taman kota 17 Mei yang ada di Tapin ini pada umumnya adalah tempat rekreasi bagi masyarakat di Kabupaten Tapin Rantau, Provinsi Kalimantan Selatan. Yang mana lokasinya itu berada tepat di ibu kota Kabupaten Tapin Rantau, yang terletak di Jalan Hasan Basri, Rantau Kiwa, Tapin Utara. Bersebelahan dengan Lapangan sepakbola Dwi Dharma Rantau.
\end{abstract}

Kata Kunci : Taman 17 Mei, Sumber Belajar IPS

PENDAHULUAN

Taman sendiri merupakan sebuah lahan yang ditata kelola dan difungsikan agar kebahagiaan. (Laurie,1986:9) Taman kota sendiri adalah sebuah wadah terjadinya rekreasi masyarakat (Setiyaningrum, Diyah,2002:4). Taman sendiri biasanya terletak wilayah jantung kota yang mana luas suatu taman itu tergantung dari luas wilayah tersebut. Yang mana sebuah taman itu didirikan dengan tujuan sebagai wadah bersantai dan juga tempat rekreasi yang difungsikan secara umum bisa didatangi masyarakat umum khususnya daerah kabupaten atau kota daerah taman tersebut. Misalnya seperti salah satu taman yang berdada di pusat kota kabupaten Tapin yakni taman 17 Mei . Tetapi Taman kota 17 Mei di Tapin ini tidak hanya menjadi tempat rekreasi saja, tetapi juga terdapat relief sejarah perjuangan masyarakat Banjar 
dan juga naskah proklamasi kemerdekaan dari masyarakat Banua Anam yang mana bisa dimanfaatkan sebagai sumber belajar IPS.

Menurut pendapat Sanjaya (2010: 228) yang dimaksud dengan sumber belajar itu merupakan semua hal yang bisa dimanfaatkan disekitar lingkungan tentunya untuk membantu ketercapaian dalam pembelajaran yang berfungsi guna mencapai efektivitas pemahaman peserta didik. Nah yang mana dilingkungan taman kota 17 Mei di Tapin ini bisa menjadi sumber belajar IPS yang menarik bagi peserta didik. Karena seorang guru haruslah kreatif dan memiliki inovasi dalam merancang sebuah pembelajaran agar pembelajaran itu berjalan dengan baik dan juga efektif.

Yang mana taman kota 17 Mei ini memiliki potensi yang sangat menarik untuk di manfaatkan sebagai sumber belajar IPS baik untuk outdoor ataupun indoor yang mana jika indoor seorang guru bisa membuatkan foto atau video tentang sejarah perjuangan masyarakat Banjar melawan para tentara kompeni Belanda dengan menjadikan Taman kota 17 Mei ini sebagai sumber belajar ataupun juga dengan kunjungan langsung dengan peserta didik. Sebuah potensi ciri khas lokal sebuah masyarakat di dalam IPS tentunya dapat dilaksanakan yakni menerka dan menganalisis serta mengoptimalkan hal yang menarik disekitaran lingkungan. Yang man diharapkan bisa mewujudkan kepekaan peserta didik. (Subiyakto, B., \& Mutiani, M.,2019). Yang mana seorang guru haruslah bisa mengoptimalkan dan menerapkan kedalam pembelajaran hal yang ada di sekitaran peserta didik sebagai sumber belajar yang menarik.

\section{PEMBAHASAN}

Berdasarkan penjelasan Dirjen Dikti (2004: 12) dikatakan bahwa yang dimaksud dengan sumber belajar itu adalah semua hal baik itu berupa tempat seseorang untuk mempelajari suatu hal. Sedangkan Degeng berpendapat (1990: 83) dikatakan bahwa yang namanya sumber pembelajaran itu adalah segala hal yang bisa menjadikan perilaku untuk belajar.

Pada saat berlangsungnya pembelajaran beberapa aspek sumber pembelajaran bisa dioptimalkan bisa berupa sumber pembelajaran yang telah terencana atau pun sebuah sumber belajar yang bisa dioptimalkan secara langsung. Dalam sumber pembelajaran diliputi oleh beberapa hal antara lain : pesan, orang, bahan, alat, teknik, dan latar. (Subiyakto, B., \& Abbas, E. W.,2020).

Taman 17 Mei ini memang sangatlah tepat dan menarik untuk dimanfaatkan untuk wadah sumber pembelajaran IPS karena termasuk aspek yang dapat merangsang pengetahuan peserta didik dalam pembelajaran khususnya dengan pendekatan sejarah dalam pembelajaran yang nantinya akan disampaikan kepada peserta didik. Yang mana suatu bahan ajar yang 
sinkron tentunya bisa dikatakan dapat menjadi materi ajar IPS (Abbas, E. W., Handy, M. R. N., Shaleh, R. M., \& Hadi, N. T. F. W. 2020).

Taman 17 Mei Tapin ini sangatlah relevan jika dimanfaatkan sebagai sumber belajar IPS khususnya dalam pembelajaran sejarah. Sejarah adalah memori kolektif sebuah bangsa, karena dalam sejarah terhimpun pengalaman perjalanan manusia sebagai bangsa berperadaban yang diawetkan sebagai pengetahuan dan pelajaran untuk generasi sekarang dan akan datang (Handy, M. R. N. 2015). pembelajaran harus dikemas dalam kemasan pembelajaran yang menarik dengan memacu siswa berpikir historis (Handy, M. R. N. 2015). Pada era kemajuan IPTEK saat ini penting sekali pembahasan materi ajar dengan pendekatan historis secara mendalam dengan tujuan diharapkan dapat membangun karakteristik peserta didik yang mempunyai kebanggaan terhadap sejarah (Handy, M. R. N. 2021).

Untuk itulah pemanfaatan taman kota 17 Mei di Tapin ini sebagai sumber belajar tentunya pembelajaran akan tersampaikan dengan baik kepada peserta didik tentunya daya serap peserta didik lebih baik dan juga peserta didik lebih bergairah dalam mengikuti proses pembelajaran.Taman kota 17 Mei Tapin ini sudah cukup lama keberadaannya. Yang mana dibangun oleh kesepakatan panitia pembagunan monumen perjuangan yang ada Kabupaten Tapin Rantau.Yang mana dipimpin langsung oleh Bupati Tapin pada masanya yaitu oleh H.Ahmad Makkie. Yang mana dipercayakan kepada H. Saberan Duul sebagai arsitek untuk mendesignnya yang mana dilaksanakan oleh tim pelaksana yaitu oleh Isti Bowo dan H.M Saleh. Nah Taman 17 Mei Tapin kota Tapin ini sendiri pada masa peresmiannya di resmikan langsung oleh bapak Menteri Sekretaris Negara yang menjabat pada masa itu yaitu oleh Sudharmono SH, yang pada 27 Juli 1085 yang lalu telah meresmikan taman kota 17 Mei Tapin ini hingga berdiri sampai sekarang. Lingkungan dan aktivitas kehidupan sosial merupakan sumber belajar utama dalam pembelajaran IPS (Putro, H. P. N. 2020).

Penguatan tentang peristiwa bersejarah dimasa lampau yang harus dituangkan kedalam materi ajar agar generasi bangsa memiliki identitas bangsa dan tidak terpengaruh dengan identitas budaya asing (Putro, H. P. N. 2020). Taman 17 Mei Tapin ini bisa menumbuhkan revitalisasi sejarah bagi peserta didik sehingga menumbuhkan sikap nasionalisme didalam jiwa peserta didik. Sumber pembelajaran sendiri menjadikan proses belajar mengajar secara nyata dan faktual (Depdiknas1983:7 dalam Karwono 2010).

Jadi yang dimaksud dengan sumber ajar itu merupakan aspek saat proses belajar mengajar agar seseorang itu bisa mendapatkan ilmu pengetahuan. belajar dan juga belajar dan apabila tidak adanya bahan ajar tentunya aktivitas belajar mengajar tidak akan berjalan dengan 
optimal. (Sitepu, 2014: 18). Bahan ajar atau sumber pembelajaran merupakan semua hal bisa dimanfaatkan untuk materi ajar (Sutikno, 2013:37).

Sumber ajar atau bahan ajar sebenarnya bisa dijadikan semua sesuatu yang bisa mempermudah proses pembelajaran agar mendapatkan ilmu pengetahuan tentunya yang diperlukan. (Mulyasa, 2012: 156). Jadi yang dimaksud dengan arti sumber belajar merupakan semua hal yang dapat dimanfaatkan dalam pembelajaran. Untuk efektivitas dan ketercapaian pembelajaran yang mana bertujuan untuk menunjang efektivitas ketercapaian pada proses belajar. Komponen sumber belajar itu meliputi pesan, orang, bahan, peralatan, teknik, dan lingkungan atau latar (dalam Komalasari, 2013: 108) . Jadi taman 17 Mei ini sangatlah cocok dan tepat dimanfaatkan sebagai sumber belajar yang mana tidak hanya untuk semata tempat rekreasi tetapi juga mengandung makna serta nilai-nilai historis perjuangan masyarakat Kalimantan Selatan melawan para tentara kompeni Belanda yang mana taman ini bisa dijadikan sebagai pengingat para nenek moyang dan para pahlawan Banjar sebanua Anam untuk melaksanakan perang kemerdekaan.

Yang mana diharapkan peserta didik memiliki rasa bangga dan juga menumbuh kembangkan sikap nasionalisme peserta didik dengan menjadikan taman 17 Mei ini sebagai sumber belajar IPS yang menarik, efektif dan juga optimal dalam implementasi pembelajaran. Menurut Husamah (2013) yang dimaksud dengan langkah-langkah dalam kegiatan pembelajaran antara lain : a) guru mengajak peserta didik melakukan pembelajaran outdoor, b) Pendidik mengarahkan dan menjelaskan akan luar biasanya lingkungan sekitar peserta didik untuk dijadikan materi pembelajaran, c) Pendidik mengarahkan kepada peserta didik dalam pelaksanaan proses belajar d) Pendidik membagi peserta didik secara berkelompok e) semua kelompok yang sudah dibagikan diberi arahan oleh guru untuk berpencar untuk mengexplore pengamatan lingkungan sekitar, f) peserta didik diarahkan oleh guru untuk explore lingkungan sekitar. g) saat sudah mengimplementasikan explore lalu guru membimbing peserta didik dalam sesi diskusi, h) peserta didik diberi kesempatan untuk oleh guru secara bergantian untuk mengungkapkan keluh kesah saat pembelajaran diluar kelas i) peserta didik dan guru menyimpulkan hasil pembelajaran diluar kelas (Suharwati, S. I., \& Rahman, A. M.,2018). Berdasarkan pendapat Rustam dan Santoso (2015) Yang dimaksud dengan proses belajar outdoor itu sendiri ada pada proses pembelajaran pendidik mengarahkan peserta didik belajar secara outdoor agar peserta didik bisa melihat secara langsung di lapangan dengan tujuan untuk mencapai ketercapaian pembelajaran para peserta didik dengan lingkungannya. Menurut Vera (2012) Yang dimaksud dengan belajar outdoor adalah proses belajar mengajar seperti pada umumnya hanya saja yang membedakan itu pembelajaran ini tidak dilakukan di dalam kelas 
tapi pada pelaksanaannya itu secara outdoor seperti lingkungan terbuka sebagai wadah proses mengajar peserta didik. Pendapat Vera (2012), yang dimaksud dengan taman bermain ataupun taman sendiri adalah sebuah tempat yang sudah di tempat umum berupa lahan yang luas. Tentunya dengan adanya aktivitas ini bisa mendorong kepekeaan para peserta didik yang masih belum berjalan optimal atau belum diketahui yang pada intinya bisa menambah pengetahuan serta wawasan peserta didik tentang lingkungan sekitarnya.

Pemanfaatan taman kota 17 Mei di Tapin ini bisa dijadikan sumber belajar diluar kelas untuk mengajak peserta didik melihat langsung lingkungannya. Efektivitas pembelajaran menurut Supriyono (2014:1) berkaca pada semua aspek pelajaran yang terstruktur demi ketercapaian hasil belajar. Efektivitas proses belajar mencapai semua aspek ketercapaian pada proses belajar. Menurut pendapat Nana Sudjana (1990:50) tentang efektivitas pada proses pembelajaran bisa diartikan sebagai suatu tindakan atau perbuatan yang mana keberhasilan peserta didik guna ketercapaian hasil belajar yang efektif dan juga optimal. Efektivitas hasil belajar tergantung dari cara guru menyampaikan materi ajar agar bisa mencapai hasil belajar yang efektif dan optimal. Lalu berdasarkan pendapat Sumardi Suryasubrata (1990:5) yang dimaksud dengan keefektifan pada proses belajar sendiri sebuah cara yang akan menghasilkan ketercapaian pembelajaran secara optimal. Tentunya dengan memanfaatkan potensi sejarah yang terkandung pada relief dinding taman kota 17 Mei Tapin ini bisa menunjang efektivitas pembelajaran yang mana akan berdampak positif terhadap ketercapaian pembelajaran dan juga terhadap kompetensi serta daya serap materi ajar yang lebih baik oleh peserta didik.

\section{SIMPULAN}

Taman 17 Mei di Tapin ini selain sebagai tempat reaksi di akhir pekan yang cukup ramai dikunjungi oleh masyarakat Tapin itu sendiri .Taman 17 Mei ini lebih dikenal oleh masyarakat Tapin dengan sebutan taman Basimban yang awal mulanya terinspirasi karena banyaknya tempat bermain anak anak-anak. Selain wadah bermain dan rekreasi sebenarnya taman 17 Mei ini mengandung makna sejarah yang mana bisa menjadi edukasi bagi anak-anak yang bermain ditaman 17 Mei ini. Taman ini jika dimanfaatkan dengan baik sebagai sumber belajar IPS tentunya akan berdampak positif terhadap pengetahuan peserta didik sehingga peserta didik peka terhadap perjuangan para pahlawan Banjar sebanua Anam untuk memperjuangkan kemerdekaan ini yang diharapkan bisa menumbuhkan kembangkan sikap nasionalisme dan patriotisme peserta didik terhadap bangsanya, sehingga di era globalisasi saat ini peserta didik tidak terpengaruh oleh kebanggaan akan negara asing. Untut itulah peranan pendidikan sangatlah penting khususnya IPS dalam membentuk dan membangun karakter bangsa yang mana bisa saja salah satunya dengan menggunakan sisi historis suatu daerah untuk 
membangkitkan semangat nasionalisme peserta didik sejak dini untuk itulah perlu sekali pemanfaatan sumber belajar yang tepat untuk menunjang efektivitas dalam pembelajaran IPS.

\section{DAFTAR PUSTAKA}

Abbas, E. W., Hidayat Putra, M. A., \& Noor Handy, M. R. (2019). Laporan Penelitian: Pemanfaatan Ekowisata Sungai Martapura Kota Banjarmasin Sebagai Sumber

Belajar Ips.Abbas, E. W., Handy, M. R. N., Shaleh, R. M., \& Hadi, N. T. F. W. (2020). Ecotourism of Martapura River Banjarmasin as a Learning Resources on Social Studies. The Innovation of Social Studies Journal, 1(2), 111-119.

Abu Ahmadi dan Supriyono. (2014). Psikologi Belajar. Jakarta: PT. Rineka Cipta.

Degeng, I Nyoman Sudana. (1990), “Media Pendidikan”. Malang:FIP IKIP Malang.

Ditjen Dikti Depdiknas. 2004. Tanya Jawab Seputar Unit dan Proses Pembelajaran di Perguruan Tinggi. Jakarta: Departemen Pendidikan Nasional. Guildford, J. P. 1956. Fundamental Sta

Handy, M. R. N. (2015). Pendidikan Sejarah dan Isu Kebangsaan.

Handy, M. R. N. (2021). Pembelajaran Sejarah Dalam Membangun Historical Awarness dan Sikap Nasionalisme Pada Peserta Didik. Prabayaksa: Journal of History Education, $1(1), 49-54$.

Husamah. (2013). Pembelajaran luar kelas outdoor learning. Jakarta : Prestasi Pustaka.

Karwono. 2010. Belajar dan Pembelajaran serta Pemanfaatannya sumber Belajar. Ciputat: Cerdas Jaya.

Komalasari, Kokom. 2013. Pembelajaran Kontekstul : Konsep dan Aplikasi. Bandung : PT.Refika Adiatama

Laurie, M. (1986). Pengantar kepada Arsitektur Pertamanan. Bandung: Intermatra.

Mulyasana, Dedi. 2012. Pendidikan Bermutu dan Berdaya Saing. Bandung: PT Remaja Rosdakarya.

Rustam, Suparjo dan Santoso, Apik Budi. 2015. Penerapan Metode Outdoor Study pada Pembelajaran Geografi Kelas X IPS MA Al Bidayah Kecamatan Bandungan Kabupaten Semarang Tahun 2014/2015. Semarang: Universitas Negeri Semarang.

Sanjaya, Wina. (2010). Strategi Pembelajaran Berorientasi Standar Proses

Sitepu, B.P., 2014. Pengembangan Sumber Belajar. Jakarta : Rajawali Press Setyaningrum, Dyah \& Febriyani Syafitri. 2012. Analisis Pengaruh Karakteristik Pemerintah Daerah Terhadap Tingkat Pengungkapan Laporan. 
Subiyakto, B., \& Mutiani, M. (2019). Internalisasi nilai pendidikan melalui aktivitas masyarakat sebagai sumber belajar ilmu pengetahuan sosial. Khazanah: Jurnal Studi Islam dan Humaniora, 17(1), 137-166.`

Subiyakto, B., \& Abbas, E. W. (2020). Strategi Pembelajaran IPS: Konsep dan Aplikasi.

Sudjana, Nana. 1990. Teori-teori Belajar Untuk Pengajaran. Bandung: Fakultas Ekonomi UI.

Suharwati, S. I., \& Rahman, A. M. (2018). Menumbuhkan Karakter Cinta Lingkungan dalam Pembelajaran IPS di Sekolah Dasar Melalui Outdoor Study.

Sumadi Suryabrata. (1990). Psikologi Pendidikan. Jakarta: PT Rajawali.

Sutikno, Sobry. 2013. Belajar dan Pembelajaran. Lombok: Holistica.

Putro, H. P. N. (2020). UJIAN NASIONALISME INDONESIA PADA AWAL REFORMASI.

Putro, H. P. N. (2020). Revitalisasi Nilai-Nilai Transportasi Tradisional dalam Pembelajaran IPS di Kalimantan Selatan 